\title{
Data report: Pleistocene planktonic foraminifers from the Kumano forearc basin, IODP Expedition 338 Holes C0002K and C0002L'
}

\author{
Hiroki Hayashi, ${ }^{2}$ Koji Suzuki, ${ }^{3,4}$ and Maya Fujimoto ${ }^{2}$
}

\begin{abstract}
Chapter contents

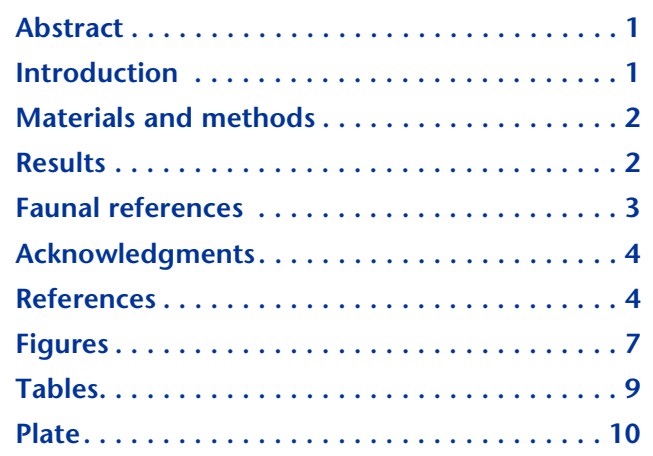

${ }^{1}$ Hayashi, H., Suzuki, K., and Fujimoto, M., 2016. Data report: Pleistocene planktonic foraminifers from the Kumano forearc basin, IODP Expedition 338 Holes C0002K and C0002L. In Strasser, M., Dugan, B., Kanagawa, K., Moore, G.F., Toczko, S., Maeda, L., and the Expedition 338 Scientists, Proceedings of the Integrated Ocean Drilling Program, 338: Yokohama (Integrated Ocean Drilling Program).

doi:10.2204/iodp.proc.338.205.2016

${ }^{2}$ Shimane University, Department of Earth

Sciences, Interdisciplinary Graduate School of Science and Engineering, 1060 Nishikawatsucho, Matsue City, Shimane 690-8504, Japan.

Correspondence author:

hayashi@riko.shimane-u.ac.jp

${ }^{3}$ Chiba University, Department of Earth Sciences, Graduate School of Science, Chiba City, Chiba 263-8522, Japan.

${ }^{4}$ Present address: Kanto Natural Gas Development Co., Ltd., Mobara City, Chiba 297-8550, Japan.

\begin{abstract}
This study describes the planktonic foraminiferal assemblages of Holes C0002K and C0002L drilled during Integrated Ocean Drilling Program Expedition 338 in the southern part of the Kumano forearc basin, northwestern Pacific Ocean. The stratigraphic interval of the studied holes is constrained within the Calabrian stage of the Pleistocene by onboard stratigraphic data. Thirty-six taxa belonging to fifteen genera of planktonic foraminifers were detected from the studied interval. Three biostratigraphic events of planktonic foraminifers were newly constrained at the present site. The planktonic foraminiferal assemblages mainly consist of mixed-water and cosmopolitan species associated with tropical and subtropical taxa.
\end{abstract}

\section{Introduction}

The Nankai Trough Seismogenic Zone Experiment (NanTroSEIZE) was designed to investigate the fault mechanics and seismogenesis of the repeated mega-earthquake zone along the subduction boundary of the Philippine Sea plate. Site C0002 is the centerpiece of this project to access the seismogenic zone beneath the Kumano forearc basin. Integrated Ocean Drilling Program (IODP) Expedition 338 was conducted as part of the third stage of the NanTroSEIZE project. The main purpose of the expedition was to extend and case riser Hole C0002F from 856 to $3600 \mathrm{~m}$ core depth below seafloor (CSF-A). However, because of damage to the riser system under severe weather conditions during the expedition, riser operations were canceled. Contingency riserless coring at Site C0002 was conducted to sample the upper part of the forearc basin sediment (see the "Expedition 338 summary" chapter [Strasser et al., 2014a]).

Precise stratigraphic correlation is required to reconstruct the deformation processes of the Nankai Seismogenic Zone. Planktonic foraminiferal biostratigraphy is a powerful tool for correlating marine strata. In previous NanTroSEIZE expeditions, planktonic foraminifers provided stratigraphic datums (e.g., Hayashi et al., 2011, 2014). For Site C0002, 14 biohorizons were recognized in Hole C0002B from 478.28 to 1052.40 m CSF-A during Expedition 315 (Expedition 315 Scientists, 2009). For Hole C0002D of Expedition 315, detailed chemostratigraphy was constructed from 
0 to $100 \mathrm{~m}$ CSF-A, reaching marine isotope Stage (MIS) 23 (Matsuzaki et al., 2015).

During Expedition 338, the D/V Chikyu drilled at Site $\mathrm{C} 0002\left(33^{\circ} 18^{\prime} \mathrm{N}, 136^{\circ} 38^{\prime} \mathrm{E}\right.$; $1937.5 \mathrm{~m}$ water depth) in the southern part of the Kumano forearc basin in the northwest Pacific Ocean (Fig. F1). In Holes C0002K and C0002L, a total of 35 cores were cut from 200 to $505 \mathrm{~m}$ CSF-A. Two of those cores were recovered with the hydraulic piston coring system (HPCS), four with the extended punch coring system (EPCS), and 29 with the extended shoe coring system (ESCS). The average recovery for the holes was $69 \%$ and $79 \%$, respectively. This coring interval was chosen to provide data within the gap (200-500 m CSF-A) between Holes C0002D and C0002B.

According to onboard stratigraphic analyses, Holes C0002K and C0002L are constrained in age between 1.34 and $0.903 \mathrm{Ma}$ and include the Jaramillo Subchron (0.988-1.07 Ma) in the upper part (Fig. F2). Onboard geochemical analyses detected a gas hydrate zone (200-400 m CSF-A) and a minimum concentration zone of salinity, chlorinity, and $\mathrm{Na}^{+}$in pore water (300-500 m CSF-A) resulting from dissociation of methane hydrate (see the "Site C0002" chapter [Strasser et al., 2014c]). The purpose of this study is to describe the planktonic foraminiferal assemblages obtained from Holes C0002K and C0002L as a basic data set for the stratigraphy of the Kumano Basin region.

\section{Materials and methods}

The samples used for this research were collected from Holes $\mathrm{C} 0002 \mathrm{~K}$ and $\mathrm{C0002 \textrm {L }}$ at an average interval of $3.5 \mathrm{~m}$ (1-3 samples per core). We treated 79 samples in the present study. The stratigraphy of the studied interval correlates to lithologic Unit II of previous drilling at Site C0002. Unit II is mainly composed of dark olive-gray silty claystone with subordinate sandstone, sandy siltstone, and volcanic ash (see the "Site C0002" chapter [Strasser et al., $2014 \mathrm{c}]$ ). We generally followed the analytical techniques described in the "Methods" chapter (Strasser et al., 2014b). Sediment samples of 10-40 g dry weight were disaggregated using the sodium tetraphenylborate method (Hanken, 1979). After the samples had been macerated, each was wet-sieved through a $63 \mu \mathrm{m}$ screen. Dried samples were then divided by a sample splitter into suitable volumes yielding 200 planktonic foraminiferal specimens. Planktonic foraminiferal specimens larger than 125 $\mu \mathrm{m}$ were picked under a binocular microscope. We then conducted additional observations for all washed residues to detect index species. Species detected by the additional observation were recorded as "+" in occurrence table (Table T1). Scanning electron microphotographs of important species were obtained with a JCM-5000 instrument (JEOL Co. Ltd., Japan).

Preservation of each sample was recorded using the following criteria:

$\mathrm{P}=$ poor (dissolution of surface structure and fragmentation are observed; more than a half of the individuals cannot be identified at the species level).

$\mathrm{M}=$ moderate (dissolution and fragmentation are commonly evident; some individuals are hard to identify).

$\mathrm{G}=$ good (no dissolution; fragmentation of individuals has slightly occurred).

Taxonomic names and biochronology in this study generally follow the usage of Wade et al. (2011). Moreover, we distinguished the two morphotypes of Globorotalia inflata (i.e., transitional and modern forms by the number of chambers [Hayashi et al., 2003]). The modern form differs from the transitional form in having three chambers in its last whorl, in contrast to the four chambers of the transitional form.

\section{Results}

With the exception of several barren intervals, 36 taxa belonging to 15 genera of planktonic foraminifers were recognized in Holes C0002K and C0002L (Table T1). Fossil preservation is generally moderate to poor. In particular, sediment below 300 m CSF-A have sparse occurrences of planktonic foraminifers with poor preservation and barren intervals (Table T1; Fig. F2). Most of these barren intervals contain only thick-walled benthic foraminifers with surfaces disfigured by dissolution.

Six age-diagnostic species were recognized in this study (Table T1). Globorotalia tosaensis sporadically occurs at 12 horizons between Samples 338-C0002L21X-6, 45.0-47.5 cm (472.89 m CSF-A), and 338C0002K-1H-5, 21.0-24.0 cm (203.57 m CSF-A). Globorotalia truncatulinoides was observed sporadically at 12 horizons between the same samples. Rare or few occurrences of Globoturborotalita obliquus were observed from only four samples $(338-\mathrm{C} 0002 \mathrm{~K}-7 \mathrm{X}$ CC, $6.0-8.0 \mathrm{~cm}$, and 338-C0002L-14X-8, 58.0-60.5 $\mathrm{cm}$; $15 \mathrm{X}-1,51.0-53.5 \mathrm{~cm}$; and 19X-1, $43.0-45.5 \mathrm{~cm}$ ). Among them, the uppermost occurrence in Sample $338-C 0002 \mathrm{~K}-7 \mathrm{X}-\mathrm{CC}, 6.0-8.0 \mathrm{~cm}$, might be reworked because the surface was brown and the test was filled by silty material (Plate P1; figs. 7a, 7b). Therefore, the top occurrence datum of this species $(1.30 \mathrm{Ma}$; Wade et al., 2011) is suggested between Samples 338- 
C0002L-14X-8, 58.0-60.5 cm (409.25 m CSF-A), and 14X-5, 81.0-83.5 cm (405.44 m CSF-A) (Table T2). A few specimens of Neogloboquadrina inglei were obtained from 18 samples between Samples 338C0002L-21X-6, 45.0-47.5 cm (472.89 m CSF-A), and 338-C0002K-1H-5, 21.0-24.0 cm (203.57 m CSF-A). This species was reported from the deeper interval drilled in Hole C0002B (Expedition 315 Scientists, 2009). Thus, the base occurrence datum of this species should be located below Sample 338-C0002L21X-6, 45.0-47.5 cm (472.89 m CSF-A) (Table T2). Pulleniatina obliquiloculata was found in 19 samples, and its coiling direction is exclusively dextral throughout the section. Pulleniatina finalis was detected at only four horizons in Hole C0002L (Samples 338-C0002L-5X-1, 20.0-22.5 cm; 13X-7, 7.0-9.5 $\mathrm{cm} ; 14 \mathrm{X}-5,81.0-83.5 \mathrm{~cm}$, and $15 \mathrm{X}-1,51.0-53.5 \mathrm{~cm}$ ). This species was detected from only one sample in deeper interval obtained from Hole C0002B (Expedition 315 Scientists, 2009). The base occurrence datum of this species (2.04 Ma; Wade et al., 2011) is hard to recognize because of its sparse occurrence.

The first occurrence of G. truncatulinoides is at 1.98 Ma (Wade et al., 2011) and defines the base of Zone N22 of Blow (1969). This biohorizon was previously recognized at deeper depths (753.86-767.20 m CSFA) in Hole C0002B during Expedition 315. In addition, the last occurrence of $G$. tosaensis is at $0.61 \mathrm{Ma}$ (Wade et al., 2011). Therefore, the interval below the top occurrence of G. tosaensis (Sample 338-C0002K1H-5, 21.0-24.0 cm; 203.57 m CSF-A) (Table T2) should be restricted to within the lower part of Zone $\mathrm{N} 22$. This correlation is consistent with onboard calcareous nannofossil and paleomagnetic data (see the "Site C0002" chapter [Strasser et al., 2014c]) (Fig. F2).

Planktonic foraminiferal assemblages in the study interval are characterized by dominant occurrences of mixed-water and cosmopolitan species such as Neogloboquadrina incompta, Neogloboquadrina pachyderma (dextral), Globigerinita glutinata, Globigerina bulloides, and Globigerina falconensis associated with tropical to subtropical taxa including Globoconella inflata, Neogloboquadrina dutertrei, and Globigerinoides ruber (Table T1; Fig. F2). Currently, the study area lies beneath mixed water caused by the upwelling of cold water near the Kuroshio Current. Therefore, the foraminiferal composition of the studied interval is generally consistent with presentday oceanographic conditions.

The most noteworthy feature of the planktonic foraminiferal assemblages is cyclic changes of relative abundance in cold versus cosmopolitan components (Fig. F2). We can observe five 40-60 m thick cycles throughout the study interval. The precise correla- tion of the cycles with global events requires further studies including stable isotope analyses.

\section{Faunal references}

Globigerina bulloides d'Orbigny, 1826; Banner and Blow, 1960, pl. 1, figs. 1-4 (Pl. P1, figs 1a, 1b).

Globigerina falconensis Blow, 1959, p. 177, pl. 9, figs. 40a40c, 41.

Globigerinella calida (Parker), 1962, p. 221, pl. 1, figs. 9-13, 15.

Globigerinella siphonifera (d'Orbigny), 1839a, p. 83, pl. 4, figs. 15-18; Banner and Blow, 1960, p. 22-23, figs. 2a2c.

Globigerinita glutinata (Egger), 1893, p. 371, pl. 13, figs. 1921 (Pl. P1, figs. 2a, 2b).

Globigerinita iota Parker, 1962, p. 250, pl. 10, figs. 26-30.

Globigerinita uvula (Ehrenberg), 1861, pl. 2, figs. 24-25.

Globigerinoides conglobatus (Brady), 1879, p. 28; Brady, 1884, pl. 80, figs. $1-5$.

Globigerinoides elongatus (d'Orbigny), 1826, p. 277; Banner and Blow, 1960, p. 12-13, pl. 3, figs. 10a-10c.

Globigerinoides ruber (d'Orbigny), 1839a, p. 82, pl. 4, figs. 12-14 (Pl. P1, figs. 3a, 3b).

Globigerinoides sacculifer (Brady), 1877, p. 535; Brady, 1884, pl. 80, figs. 11-17; Banner and Blow, 1960, p. 21, pl. 4, fig. 1.

Globoconella inflata (d'Orbigny), 1839b, p. 134, pl. 12, figs. 7-9 (Pl. P1, figs. 4a, 4b).

Globoconella puncticulata (Deshayes), 1832, p. 170; Banner and Blow, 1960, pt. 1, p. 15, pl. 5, figs. 7a-7c.

Globorotalia crassaformis crassaformis (Galloway and Wissler), 1927, p. 41, pl. 7, fig. 12.

Globorotalia crassaformis viola Blow, 1969, p. 397, pl. 5, figs. 4-9.

Globorotalia tosaensis Takayanagi and Saito, 1962, p. 81, pl. 28, figs. 11a-12c (Pl. P1, figs. 5a-5c).

Globorotalia truncatulinoides (d'Orbigny), 1839b, p. 132, pl. 2, figs. 25-27 (Pl. P1, figs. 6a-6c).

Globorotalia tumida (Brady), 1877, p. 535; Brady, 1884, pl. 103, figs. 4-6.

Globorotaloides hexagona (Natland), 1938, p. 149, pl. 7, figs. 1a-1c.

Globorotaloides variabilis Bolli, 1957, p. 117, pl. 27, figs. 15a-20c.

Globoturborotalita obliquus (Bolli), 1957, p. 113, pl. 25, figs. 10a-10c (Pl. P1, figs. 7a-8b).

Globoturborotalita rubescens (Hofker), 1956, p. 234, pl. 32, fig. 26.

Globoturborotalita tenella (Parker), 1958, p. 280, pl. 6, figs. 7-11.

Hirsutella scitula (Brady), 1882, p. 716; Banner and Blow, 1960, pt. 1, p. 27, pl. 5, fig. 5.

Menardella cultrata (d'Orbigny), 1839a, p. 76, pl. 5, figs, 79; Banner and Blow, 1960, pl. 6, fig. 1.

Menardella menardii (Parker, Jones and Brady), 1865, Pt. XII; Stainforth et al., 1978, pl. 1, fig. 1.

Neogloboquadrina dutertrei (d'Orbigny), 1839a, p. 84, pl. 4, figs. 19-21; Banner and Blow, 1960, pt. 1, pl. 2, fig. 1 (Pl. P1, figs. 10a, 10b). 
Neogloboquadrina incompta (Cifelli), 1961, p. 83, pl. 4, figs. 1-7 (Pl. P1, figs. 11a, 11b).

Neogloboquadrina inglei Kucera and Kennett, 2000 (P1. P1, figs. 9a, 9b).

Neogloboquadrina pachyderma (Ehrenberg), 1861, p. 276; Banner and Blow, 1960, pt. 1, p. 4, pl. 3. figs. 4a-4c (Pl. P1, figs. 12a, 12b).

Orbulina universa d'Orbigny, 1839a, p. 3, pl. 1, fig. 1.

Pulleniatina finalis Banner and Blow, 1967, p. 140, pl. 2, figs. 4-10 (Pl. P1, fig. 14).

Pulleniatina obliquiloculata (Parker and Jones), 1865, p. 368, pl. 19, figs. 4a-4b (Pl. P1, figs. 13a, 13b).

Sphaeroidinella dehiscens (Parker and Jones), 1865, p. 369, pl. 19 , fig. 5.

Turborotalita quinqueloba (Natland), 1938, p. 149, pl. 6, figs. 7a-7c.

\section{Acknowledgments}

We would like to express our appreciation to Dr. Koji Kameo of Chiba University for his valuable suggestions. We are also grateful to Dr. Brandon Dugan, Dr. $\mathrm{Xin} \mathrm{Su}$, and an anonymous reviewer for valuable comments which improved our manuscript. This research used samples provided by the Integrated Ocean Drilling Program (IODP). This study was funded by Grants-in-Aids 23740377 and 15K05311 from the Japan Society for the Promotion of Science. Figure F1 was produced by GMT software developed by Wessel and Smith (1991).

\section{References}

Banner, F.T., and Blow, W.H., 1960. Some primary types of species belonging to the superfamily Globigerinaceae. Contributions from the Cushman Foundation for Foraminiferal Research, 11(1):1-41.

Banner, F.T., and Blow, W.H., 1967. The origin, evolution and taxonomy of the foraminiferal genus Pulleniatina Cushman, 1927. Micropaleontology, 13(2):133-162. http://dx.doi.org/10.2307/1484667

Blow, W.H., 1959. Age, correlation, and biostratigraphy of the upper Tocuyo (San Lorenzo) and Pozón formations, eastern Falcón, Venezuela. Bulletins of American Paleontology, 39(178):59-252.

Blow, W.H., 1969. Late middle Eocene to Recent planktonic foraminiferal biostratigraphy. Proceedings of the First International Conference on Planktonic Microfossils, 199-422.

Bolli, H.M., 1957. Planktonic foraminifera from the Oligocene-Miocene Cipero and Lengua formations of Trinidad, B.W.I. In Loeblich, A.R., Jr., Tappan, H., Beckmann, J.P., Bolli, H.M., Gallitelli, E.M., and Troelsen, J.C. (Eds.), Studies in Foraminifera. Bulletin of the United States National Museum, 215:97-123.

Brady, H.B., 1877. Supplementary note on the foraminifera of the Chalk (?) of the New Britain Group. Geological
Magazine, 4:534-546. http://dx.doi.org/10.1017/ S0016756800150137

Brady, H.B., 1879. Notes on some of the reticularean Rhizopoda (Foraminifera and Polycystina) of the NorthPolar Expedition of 1875-76. Annals and Magazine of Natural History, 5:425-452.

Brady, H.B., 1882. Report on the Foraminifera. In Tizard, L., and Murray, J. (Eds.), Exploration of the Faröe Channel During the Summer of 1880, in Her Majesty's Ship Knight Errant, with Subsidiary Reports. Proceedings of the Royal Society of Edinburgh, 11:708-717.

Brady, H.B., 1884. Report on the Scientific Results of the Voyage of the H.M.S. Challenger, during the years 1873-1876 (Volume IX): Foraminifera: Edinburgh (Neill and Company).

Cifelli, R., 1961. Globigerina incompta, a new species of pelagic foraminifera from the North Atlantic. Contributions from the Cushman Foundation for Foraminiferal Research, 12(3):83-86.

d'Orbigny, A.D., 1826. Tableau méthodique de la classe des Céphalopodes. Annals des Sciences Naturelles, Paris, Ser. 1, 7:245-314.

d'Orbigny, A.D., 1839a. Foraminifères. In de la Sagra, R. (Ed.), Histoire Physique, Politique et Naturelle de Lîle de Cuba (Volume 8): Paris (Arthus Bertrand).

d'Orbigny, A.D., 1839b. Foraminifères des Îles Canaries. In Barker-Webb, P., and Berthelot, S. (Eds.), Historie Naturelle des Illes Canaries (Volume 2, Part 2): Paris (Béthune), 119-146.

Deshayes, G.P., 1832. Encyclopédia méthodique. Histoire Naturelle des Vers, 2:1-594.

Egger, J.G., 1893. Foraminiferen aus Meeresgrundproben gelothet von 1874 bis 1876 von S. M. Sch. Gazelle. Abhandlungen, Bayerische Akademie der Wissenschaften, Mathematisch-Physikalische Klasse, 18(2):193-458.

Ehrenberg, C.G., 1861. Elemente des tiefen Meeresgrundes in Mexikanischen Golfstrome bei Florida; Ueber die Tiefgrund-Verhältnisse des Oceans am Eingang der Davisstrasse und bei Island. Monatsberichte der Koeniglichen Preussischen Akademie der Wissenschaften zu Berlin, 222-240, 275-315.

Expedition 315 Scientists, 2009. Expedition 315 Site C0002. In Kinoshita, M., Tobin, H., Ashi, J., Kimura, G., Lallemant, S., Screaton, E.J., Curewitz, D., Masago, H., Moe, K.T., and the Expedition 314/315/316 Scientists, Proceedings of the Integrated Ocean Drilling Program, 314/ 315/316: Washington, DC (Integrated Ocean Drilling Program Management International, Inc.). http:// dx.doi.org/10.2204/iodp.proc.314315316.124.2009

Galloway, J.J., and Wissler, S.G., 1927. Pleistocene foraminifera from the Lomita Quarry, Palos Verdes Hills, California. Journal of Paleontology, 1(1):35-87. http://www.jstor.org/stable/1298073

Hanken, N.-M., 1979. The use of sodium tetraphenylborate and sodium chloride in the extraction of fossils from shales. Journal of Paleontology, 53(3):738-741. http://www.jstor.org/stable/1304012

Hayashi, H., Asano, S., Yamashita, Y., Tanaka, T., and Nishi, H., 2011. Data report: late Neogene planktonic foraminiferal biostratigraphy of the Nankai Trough, IODP Expe- 
dition 315. In Kinoshita, M., Tobin, H., Ashi, J., Kimura, G., Lallemant, S., Screaton, E.J., Curewitz, D., Masago, H., Moe, K.T., and the Expedition 314/315/316 Scientists, Proceedings of the Integrated Ocean Drilling Program, 314/315/316: Washington, DC (Integrated Ocean Drilling Program Management International, Inc.). http:// dx.doi.org/10.2204/iodp.proc.314315316.206.2011

Hayashi, H., Morishita, C., and Oda, M., 2003. Neogene planktonic foraminiferal biostratigraphy of the Japan Trench, ODP Leg 186. In Suyehiro, K., Sacks, I.S., Acton, G.D., and Oda, M. (Eds.), Proceedings of the Ocean Drilling Program, Scientific Results, 186: College Station, TX (Ocean Drilling Program), 1-23. http://dx.doi.org/ 10.2973/odp.proc.sr.186.114.2003

Hayashi, H., Yamashita, K., Govil, P., Idehara, Y., Tanaka, T., and Nishi, H., 2014. Data report: middle Miocene to Pliocene planktonic foraminiferal biostratigraphy of the northern part of the Shikoku Basin, IODP Exp. 322 Site C0012. In Saito, S., Underwood, M.B., Kubo, Y., and the Expedition 322 Scientists, Proceedings of the Integrated Ocean Drilling Program, 322: Tokyo (Integrated Ocean Drilling Program Management International, Inc.). http://dx.doi.org/10.2204/iodp.proc.322.206.2014

Hofker, J., Sr., 1956. Foraminifera of Santa Cruz and Thatcher Island, Virginia Archipelago, West Indies. Copenhagen University, Zoologisk Museum Spolia (Skrifler), 15:234.

Kucera, M., and Kennett, J.P., 2000. Biochronology and evolutionary implications of late Neogene California margin planktonic foraminiferal events. Marine Micropaleontology, 40(1-2):67-81. http://dx.doi.org/10.1016/S0377-8398(00)00029-3

Matsuzaki, K.M., Suzuki, N., Nishi, H., Hayashi, H., Gyawali, B.R., Takashima, R., and Ikehara, M., 2015. Early to middle Pleistocene paleoceanographic history of southern Japan based on radiolarian data from IODP Exp 314/315 Sites C0001 and C0002. Marine Micropaleontology, 118:17-33. http://dx.doi.org/10.1016/j.marmicro.2015.05.001

Natland, M.L., 1938. New species of Foraminifera from off the West Coast of North America and from the later Tertiary of the Los Angeles Basin. Bulletin of the Scripps Institution of Oceanography, 4(5):137-163.

Parker, F.L., 1958. Eastern Mediterranean Foraminifera. Reports of the Swedish Deep-Sea Expedition, 1947-1948, 8:219-283.

Parker, F.L., 1962. Planktonic foraminiferal species in Pacific sediments. Micropaleontology, 8(2):219-254. http://dx.doi.org/10.2307/1484745

Parker, W., Jones, T., Bailey, J., and Pourtales, F., 1865. On some foraminifera from the North Atlantic and Arctic Oceans, including Davis Straits and Baffin's Bay. Philosophical Transactions of the Royal Society of London, 155:325-441. http://dx.doi.org/10.1098/rstl.1865.0006

Parker, W.K., Jones, T.R., and Brady, H.B., 1865. On the nomenclature of the foraminifera, Part XII. The species enumerated by d'Orbigny in the "Annales des Sciences
Naturelles, vol. 7, 1826." Annals and Magazine of Natural History, Series 3, 16:15-41.

Stainforth, R.M., Lamb, J.L., and Jeffords, R.M., 1978. Rotalia menardii Parker, Jones and Brady, 1865 (Foraminiferida): proposed suppression of lectotype and designation of neotype Z.N. (S.) 2145. Bulletin of Zoological Nomenclature, 34(4):1-10.

Strasser, M., Dugan, B., Kanagawa, K., Moore, G.F., Toczko, S., Maeda, L., Kido, Y., Moe, K.T., Sanada, Y., Esteban, L., Fabbri, O., Geersen, J., Hammerschmidt, S., Hayashi, H., Heirman, K., Hüpers, A., Jurado Rodriguez, M.J., Kameo, K., Kanamatsu, T., Kitajima, H., Masuda, H., Milliken, K., Mishra, R., Motoyama, I., Olcott, K., Oohashi, K., Pickering, K.T., Ramirez, S.G., Rashid, H., Sawyer, D., Schleicher, A., Shan, Y., Skarbek, R., Song, I., Takeshita, T., Toki, T., Tudge, J., Webb, S., Wilson, D.J., Wu, H.-Y., and Yamaguchi, A., 2014a. Expedition 338 summary. In Strasser, M., Dugan, B., Kanagawa, K., Moore, G.F., Toczko, S., Maeda, L., and the Expedition 338 Scientists, Proceedings of the Integrated Ocean Drilling Program, 338: Yokohama (Integrated Ocean Drilling Program). http://dx.doi.org/10.2204/iodp.proc.338.101.2014

Strasser, M., Dugan, B., Kanagawa, K., Moore, G.F., Toczko, S., Maeda, L., Kido, Y., Moe, K.T., Sanada, Y., Esteban, L., Fabbri, O., Geersen, J., Hammerschmidt, S., Hayashi, H., Heirman, K., Hüpers, A., Jurado Rodriguez, M.J., Kameo, K., Kanamatsu, T., Kitajima, H., Masuda, H., Milliken, K., Mishra, R., Motoyama, I., Olcott, K., Oohashi, K., Pickering, K.T., Ramirez, S.G., Rashid, H., Sawyer, D., Schleicher, A., Shan, Y., Skarbek, R., Song, I., Takeshita, T., Toki, T., Tudge, J., Webb, S., Wilson, D.J., Wu, H.-Y., and Yamaguchi, A., 2014b. Methods. In Strasser, M., Dugan, B., Kanagawa, K., Moore, G.F., Toczko, S., Maeda, L., and the Expedition 338 Scientists, Proceedings of the Integrated Ocean Drilling Program, 338: Yokohama (Integrated Ocean Drilling Program).

http://dx.doi.org/10.2204/iodp.proc.338.102.2014

Strasser, M., Dugan, B., Kanagawa, K., Moore, G.F., Toczko, S., Maeda, L., Kido, Y., Moe, K.T., Sanada, Y., Esteban, L., Fabbri, O., Geersen, J., Hammerschmidt, S., Hayashi, H., Heirman, K., Hüpers, A., Jurado Rodriguez, M.J., Kameo, K., Kanamatsu, T., Kitajima, H., Masuda, H., Milliken, K., Mishra, R., Motoyama, I., Olcott, K., Oohashi, K., Pickering, K.T., Ramirez, S.G., Rashid, H., Sawyer, D., Schleicher, A., Shan, Y., Skarbek, R., Song, I., Takeshita, T., Toki, T., Tudge, J., Webb, S., Wilson, D.J., Wu, H.-Y., and Yamaguchi, A., 2014c. Site C0002. In Strasser, M., Dugan, B., Kanagawa, K., Moore, G.F., Toczko, S., Maeda, L., and the Expedition 338 Scientists, Proceedings of the Integrated Ocean Drilling Program, 338: Yokohama (Integrated Ocean Drilling Program).

http://dx.doi.org/10.2204/iodp.proc.338.103.2014

Takayanagi, Y., and Saito, T., 1962. Planktonic foraminifera from the Nobori Formation, Shikoku, Japan. Science Reports of the Tohoku University, Series 2: Geology, 5:647706.

Wade, B.S., Pearson, P.N., Berggren, W.A., and Pälike, H., 2011. Review and revision of Cenozoic tropical planktonic foraminiferal biostratigraphy and calibration to 
the geomagnetic polarity and astronomical time scale. Earth-Science Reviews, 104(1-3):111-142.

http://dx.doi.org/10.1016/j.earscirev.2010.09.003

Wessel, P., and Smith, W.H.F., 1991. Free software helps map and display data. Eos, Transactions of the American Geophysical Union, 72(41):441.

http://dx.doi.org/10.1029/90EO00319
Initial receipt: 20 September 2015

Acceptance: 7 April 2016

Publication: 14 June 2016

MS 338-205 
Figure F1. Map with Site C0002 and previous IODP sites around the Nankai Trough in the northwestern Pacific Ocean (modified after the Figure F1 in the "Expedition 338 summary" chapter [Strasser et al., 2014a]).

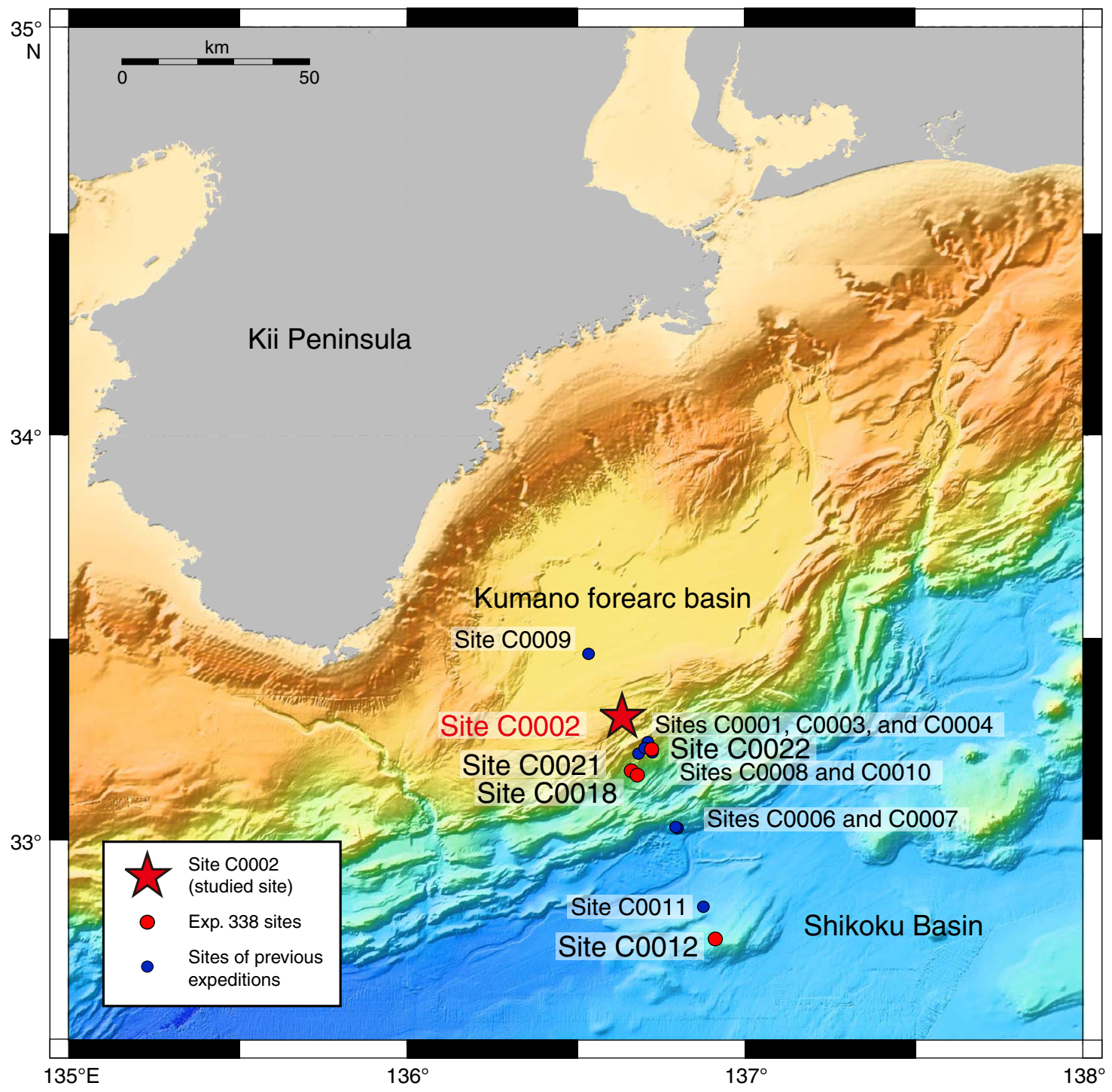


Figure F2. Stratigraphic changes in planktonic foraminiferal (PF) numbers, planktonic/total foraminiferal (P/T) ratio, and selected planktonic foraminiferal species. The $\mathrm{P} / \mathrm{T}$ ratio and relative abundance of each species are presented for samples containing $>100$ individuals. The " $N$. pachyderma group" consists of Neogloboquadrina incompta and Neogloboquadrina pachyderma. Lithology, paleomagnetic polarity, and nannofossil biohorizons $\left.{ }^{*}\right)$ are defined from onboard data (see the "Site C0002" chapter [Strasser et al., 2014c]).

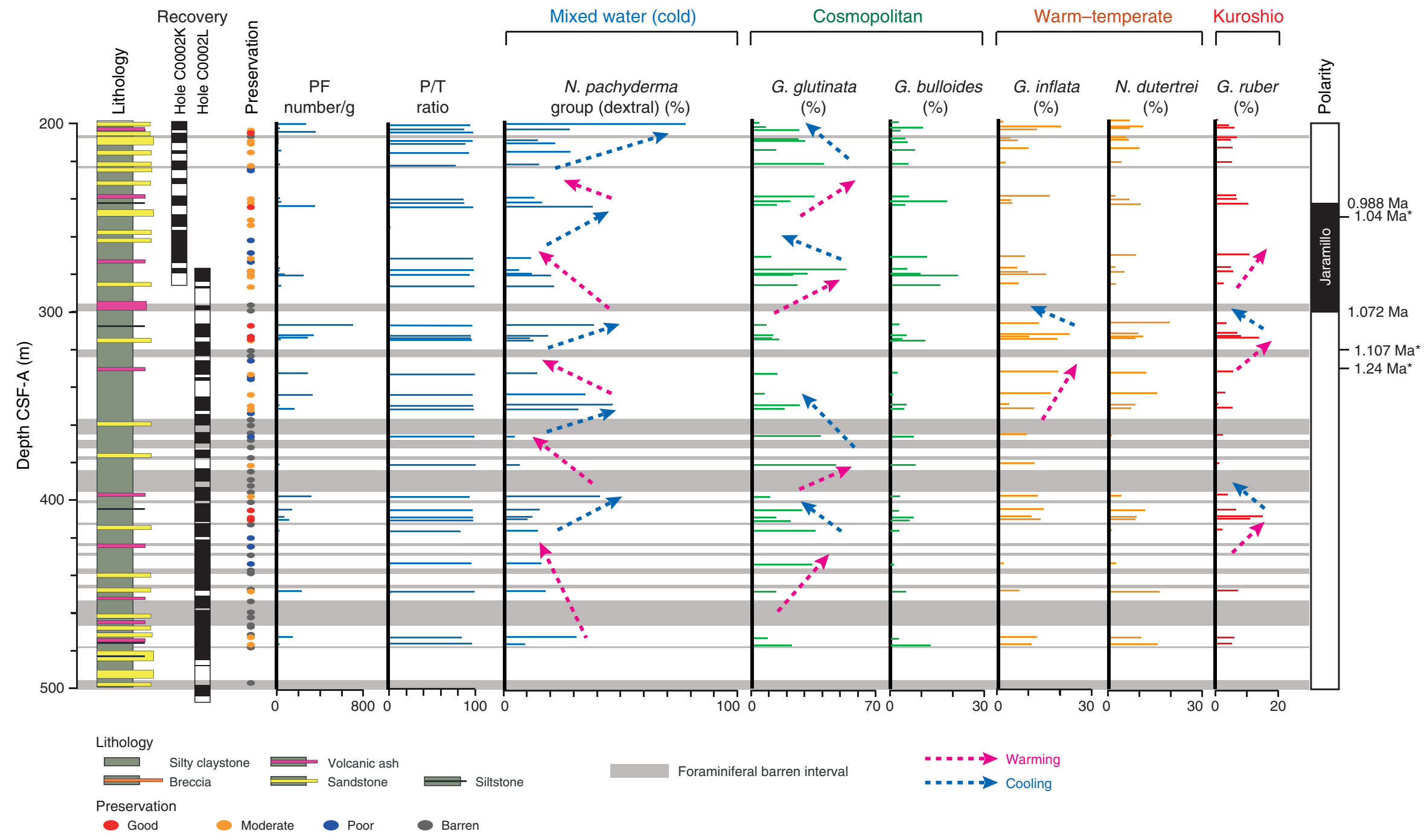


Table T1. Planktonic foraminifer range chart, Holes C0002K and C000L. This table is available in an oversized format.

Table T2. Planktonic foraminiferal events, Expedition 338.

\begin{tabular}{|c|c|c|c|c|c|c|c|}
\hline Event (base of zone) & $\begin{array}{l}\text { BW11 age } \\
\text { (Ma) }\end{array}$ & $\begin{array}{c}\text { Top } \\
\text { hole, core, section, } \\
\text { interval }(\mathrm{cm})\end{array}$ & $\begin{array}{l}\text { Depth CSF-A } \\
(\mathrm{m})\end{array}$ & $\begin{array}{c}\text { Bottom } \\
\text { hole, core, section, } \\
\text { interval }(\mathrm{cm})\end{array}$ & $\begin{array}{l}\text { Depth CSF-A } \\
(\mathrm{m})\end{array}$ & $\begin{array}{l}\text { Mean } \\
\text { depth } \\
\text { CSF-A } \\
(\mathrm{m})\end{array}$ & $\begin{array}{l}\text { Depth } \\
\text { range } \\
( \pm \mathrm{m})\end{array}$ \\
\hline & \multicolumn{2}{|c|}{$338-$} & \multicolumn{2}{|c|}{$338-$} & & & \\
\hline T Globorotalia tosaensis (PT1b) & 0.61 & - & - & C0002K-1H-5, 21.0-24.0 & 203.57 & 203.57 & - \\
\hline T Globoturborotalita obliquus & 1.30 & C0002L-14X-5, 81.0-83.5 & 405.44 & C0002L-14X-8, 58.0-60.5 & 409.25 & 407.35 & 1.91 \\
\hline B Neogloboquadrina inglei & - & C0002L-21X-6, 45.0-47.5 & 472.89 & - & - & 472.89 & - \\
\hline
\end{tabular}

BW11 = Wade et al. (2011), B = base occurrence, $\mathrm{T}=$ top occurrence. $-=$ not applicable. 
Plate P1. 1a-b. Globigerina bulloides d'Orbigny; Sample 338-C0002L-2X-1, 45.0-48.0 cm. 2a, 2b. Globigerinita glutinata (Egger); Sample 338-C0002K-2H-1, 45.0-48.0 cm. 3a, 3b. Globigerinoides ruber (d'Orbigny); Sample 338-C0002L-2X-1, 45.0-48.0 cm. 4a, 4b. Globoconella inflata (d'Orbigny) transitional form; Sample 338C0002K-2H-1, 45.0-48.0 cm. 5a, 5b. Globorotalia tosaensis Takayanagi and Saito; Sample 338-C0002K-2H-1, $45.0-48.0$ cm. 6a-6c. Globorotalia truncatulinoides (d'Orbigny); Sample 338-C0002K-7X-CC, 6.0-8.5 cm. 7a, 7b. Globoturborotalita obliquus (Bolli) reworked specimen; Sample 338-C0002K-8X-3, 79.0-81.5 cm. 8a, 8b. Globoturborotalita obliquus (Bolli); Sample 338-C0002L-14X-8, 58.0-60.0 cm. 9a, 9b. Neogloboquadrina inglei Kucera and Kennett; Sample 338-C0002K-2H-1, 45.0-48.0 cm. 10a, 10b. Neogloboquadrina dutertrei (d'Orbigny); Sample 338-C0002L-19X-1, 43.0-45.5 cm. 11a, 11b. Neogloboquadrina incompta (Cifelli) dextral; Sample 338C0002K-2H-1, 45.0-48.0 cm. 12a, 12b. Neogloboquadrina pachyderma (Ehrenberg) dextral; Sample 338-C0002K2H-1, 45.0-48.0 cm. 13a, 13b. Pulleniatina obliquiloculata (Parker and Jones); Sample 338-C0002L-4X-7, 80.0$85.0 \mathrm{~cm}$. 14. Pulleniatina finalis Banner and Blow; Sample 338-C0002L-4X-CC, $45.0-48.0 \mathrm{~cm}$. Scale bars $=100$ $\mu \mathrm{m}$.

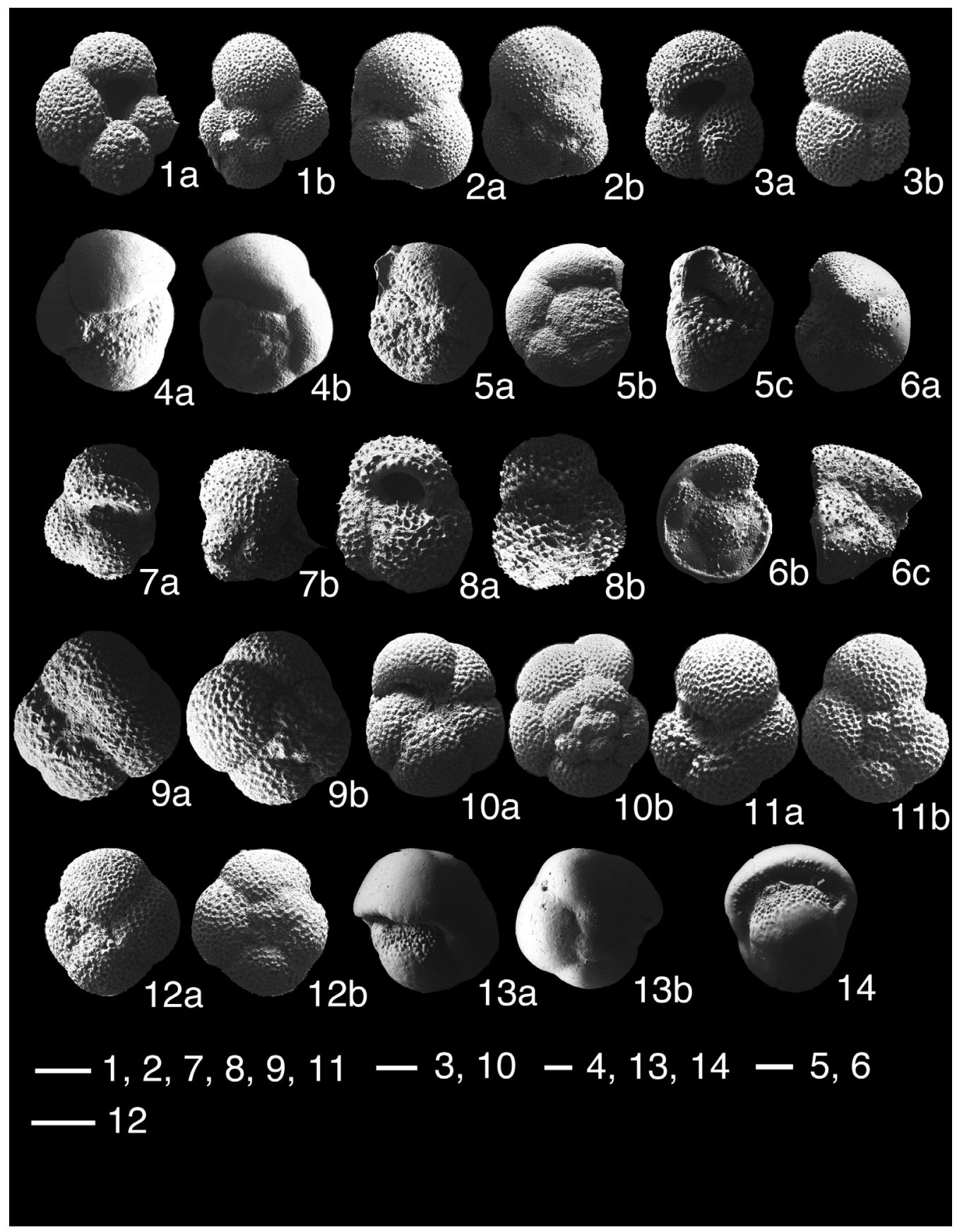

